\title{
Chemical Analysis of the Composition of Ores as the Basis for Improving the Quality of Ore Preparation
}

\author{
Bakhtiyor Kholmurodov ${ }^{1}$, Makhbuba Dzhuraeva $^{1}$, Ulugbek Sharafutdinov ${ }^{1}$, Ewgeni \\ Kuznecov $^{2}$ \\ ${ }^{1}$ Navoi Mining and Metallurgical Combinat, 210100, St. Galaba 27, Navoi, Uzbekistan \\ ${ }^{2}$ T.F. Gorbachev Kuzbass State Technical University, Mezhdurechensk Branch, 652881, 36 Stroiteley \\ av., Mezhdurechensk, Kemerovo region-Kuzbass, Russia
}

\begin{abstract}
An assessment of the existing methods of controlling the quality of mineral raw materials during mining and possible ways of increasing their efficiency is presented. Criteria for evaluating the ore massif are given, depending on the mineral and chemical composition, structural and other features. As a result of the studies, the problem of increasing the efficiency of ore preparation was solved based on the use of chemical analysis of the granulometric composition of the processed ore (charge), which provided an increase in the extraction of the useful component, which makes the model of the charge of ores from various deposits more accurate.
\end{abstract}

\section{Introduction}

Technological schemes for the processing of gold-bearing ores, depending on the characteristics of the mineral, phase, chemical, granulometric composition, the size and geometric shape of gold particles, the purity of the surface of gold grains, which determine the "obstinateness" of raw materials, are very diverse and include dozens of technological operations that combine enrichment, and chemical and metallurgical processes. The parameters of the material composition are determined during technological sampling, geological and technological modeling, which are carried out at all stages of geological work, technological assessment and industrial processing of ores [1-3].

\section{Methods}

Modern technologies have developed cycles of ore preparation operations, the main of which are:

- X-ray radiometric separation, auto- and semi-autogenous grinding;

- cascades of gravitational devices, finishing rough concentrates, methods of magnetoelectric and electronic separation, flotation processes;

- various methods of chemical leaching (heap, vat, autoclave, sorption, bacterial, "coal in pulp"); 
- methods of gold precipitation from leaching solutions (sorption-extraction, electrolysis), electrolytic refining and many other specific methods of processing ores, concentrates, mineral materials;

- pyrometallurgical processes of processing gold-bearing ores, concentrates and non-ferrous metal products [4-8].

Ore preparation is a set of ore processing activities made by various methods to obtain particle size and material compositions determined by the requirements of subsequent processing or standards for finished products. Such processing is achieved by crushing and grinding, screening and classification, agglomeration, and blending. In the mining industry, this concept is applied to ore raw materials and is an integral part of the general concept of preparing minerals for industrial use. The preparation of raw materials is classified by purpose, which determines its technological scheme. It is most widely used for beneficiation, hydrometallurgy, metallurgical and chemical processing, as well as for independent technological process for finished industrial goods producing.

Ore preparation processes used for the disclosure of all mineral forms of gold, as well as for the majority of ore raw materials, include operations of crushing, disintegration, screening, classification, grinding [9-10].

The choice of the ore preparation scheme depends on the material composition and technological properties of the mineral raw materials, the main of which are: the physical and mechanical properties of the ore, the size of the initial ore material, the required size for subsequent enrichment with the maximum possible degree of mineral disclosure and the minimum amount of over-crushed material. The main task of ore preparation processes is to obtain a crushed product of the required granulometric composition, which ensures a fairly complete opening of gold and its mineral forms.

According to the mineral composition, ores are subdivided into native, sulfide, oxidized and mixed.

Useful components in ores are presented in different forms:

- independent mineral formations;

- isomorphic impurities in the crystal lattices of ore and rock minerals;

- dispersed or sorbed in grains or on the surfaces of other minerals;

- bio-organic compounds and other forms.

According to the prevalence and significance, the minerals of gold-bearing ores are divided into ore, rock, main, minor and rare. The main ore minerals, as a rule, are the concentrators of valuable components, the main of which are contained in the ores of nonferrous and noble metals.

Minor minerals are contained in ores in small amounts and do not significantly affect the choice of technology for extracting the main valuable components. Minerals, which contain the bulk of the useful component, are concentrating minerals. Technological schemes should provide for the extraction of these minerals, as well as other valuable accompanying components.

\section{Results}

To determine the chemical composition and recovery factor of gold and silver, samples were taken from the ores of the deposits "Adzhibugut", "Karakutan" and "Beshashi" of the Ore Department "GMZ-1" of the Navoi MMC. On these samples, sorption cyanidation was carried out in the following mode: using sorption technology without preliminary cyanidation $-10.0 \mathrm{~h}$, a one-time resin load of $1.6 \%, \mathrm{NaCN}$ concentration $=350 \mathrm{mg} / 1$.

In the process of researching the original ore of the "Karakutan", "Adzhibugut", "Beshashi" deposits, a chemical analysis of the table was carried out [1]. 
Table 1. Chemical analysis of initial samples

\begin{tabular}{|c|c|c|c|c|c|c|c|c|c|}
\hline \multirow{2}{*}{ Sample name } & \multicolumn{10}{|c|}{ Content, \% } \\
\cline { 2 - 11 } & $\mathbf{A u}$ & $\mathbf{A g}$ & $\mathbf{S}_{\text {total }}$ & $\mathbf{S}_{\text {sulph }}$ & $\mathbf{C}_{\text {total }}$ & $\mathbf{C}_{\text {organ }}$ & $\mathbf{C O}_{2}$ & $\mathbf{A s}$ & $\mathbf{S b}$ \\
\hline "Karakutan" & 5.58 & 7.5 & 2.1 & 1.40 & 1.36 & 0.60 & 2.80 & 0.44 & 0.029 \\
\hline "Ajibugut" & 1.0 & 10.3 & 0.96 & $<0.2$ & 0.29 & 0.73 & 0.4 & 0.35 & 0.007 \\
\hline "Beshashi" & 1.6 & 1.3 & 0.8 & $<0.2$ & 0.21 & 0.13 & 0.29 & 0.16 & 0.006 \\
\hline
\end{tabular}

Karakutan.

The content in the original ore was: $\mathrm{Au}-5,58 \%, \mathrm{Ag}-7,5 \%, \mathrm{Fe}_{\text {total }}-3,9 \%, \mathrm{~S}_{\text {sulph }}-1,4 \%$,

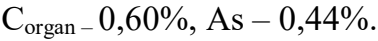

When ore was crushed to a grade of $2 \mathrm{~mm}$ (Table 2), the yield of a finished grade of 0.074 mm was $27.2 \%$, with a content of $3.95 \%$, the distribution of gold in this class was $19.3 \%$. Classes $-2.0+0.5 \mathrm{~mm}$ are distinguished for the high content of metals, with a yield of $42.2 \%$ and a gold content of $6.7 \%$, silver $8.2 \%$, the distribution in these classes was $50.8 \%$ of gold and $46.6 \%$ silver.

Table 2. Granulometric characteristics of the ore sample of the "Karakutan" deposit, crushed to a size class of $2 \mathrm{~mm}$.

\begin{tabular}{|c|c|c|c|c|c|c|c|c|}
\hline \multirow{2}{*}{$\begin{array}{c}\text { Size class, } \\
\mathbf{m m}\end{array}$} & \multirow{2}{*}{$\begin{array}{c}\text { Output, } \\
\mathbf{\%}\end{array}$} & \multicolumn{7}{|c|}{ Content of elements, \% } \\
\cline { 3 - 9 } & $\mathbf{A u}, \mathbf{g} / \mathbf{t}$ & $\mathbf{A g}, \mathbf{g} / \mathbf{t}$ & $\mathbf{S}_{\text {total }}$ & $\mathbf{S}_{\text {sulph }}$ & $\mathbf{F e}_{\text {total }}$ & $\mathbf{C O}_{\mathbf{2}}$ & $\mathbf{C}_{\text {organ }}$ \\
\hline$-2+1$ & 20.1 & 6.83 & 9.10 & 1.50 & 1.30 & 3.40 & 2.80 & 0.35 \\
\hline$-1.0+0.5$ & 22.1 & 6.57 & 7.40 & 1.50 & 1.20 & 3.20 & 2.70 & 0.37 \\
\hline$-0.5+0.25$ & 16.4 & 5.58 & 7.30 & 2.0 & 1.40 & 3.60 & 2.90 & 0.42 \\
\hline$-0.25+0.16$ & 5.4 & 5.20 & 6.60 & 2.40 & 1.30 & 4.10 & 3.30 & 0.69 \\
\hline$-0.16+0.074$ & 8.8 & 5.30 & 6.70 & 2.80 & 1.80 & 4.40 & 2.90 & 0.81 \\
\hline$-0.074+0$ & 27.2 & 3.95 & 6.70 & 2.80 & 1.60 & 4.20 & 2.90 & 0.80 \\
\hline Total & 100.0 & 5.56 & 7.43 & 2.10 & 1.42 & 3.73 & 2.86 & 0.55 \\
\hline
\end{tabular}

Mineralogical analysis determined:

- the main rock-forming minerals are quartz, feldspars, micas, hydromica and clay minerals;

- the main ore minerals are pyrite, arsenopyrite.

- hypergene minerals are very insignificantly developed and are represented by products of sulfide oxidation: iron oxides and hydroxides (hematite, limonite, goethite and hydrogoethite), iron arsenates (scorodite, etc.), sulfates (gypsum, etc.).

Rational analysis showed the presence of $75.3 \%$ free cyanide gold in the sample. The extraction of gold from the original ore by sorption cyanidation for 18 hours according to the scheme of resin in the "head" of the process was $60.9 \%$, with a gold content in the sorption tailings of $2.18 \mathrm{~g} / \mathrm{t}$. 
The best indicators for the through extraction of gold from the ore of the Karakutan deposit were obtained by the flotation-sorption scheme with preliminary superfine grinding of flotation concentrate $-82 \%$, by the gravity-flotation-sorption scheme with roasting of concentrates $-80.1 \%$.

Based on the results of laboratory studies, as an alternative option to increase the metal recovery from ores processed at the GMZ-1 RU, we will consider options for ultrafine grinding for processing concentrates, followed by their cyanidation, excluding the roasting operation.

According to assay and chemical analysis, the average content of gold and impurities is as follows: gold is $0.9-1.0 \%$, silver is $10.3 \%$, sulfide sulfur is $0.2 \%$, arsenic is $0.35 \%, \mathrm{C}_{\text {organ }}$ is $0.73 \%, \mathrm{Fe}_{\text {total }}$ is $3.4 \%$.

The result of a complete chemical analysis indicates an aluminosilicate composition of the sample, consisting mainly of rock-forming oxides $\mathrm{SiO}_{2}$. $\mathrm{Al}_{2} \mathrm{O}_{3}, \mathrm{Fe}_{2} \mathrm{O}_{3}$. The sample shows the predominance of alkaline earth oxides over carbonate ones.

The main rock-forming minerals of the oxidized ore sample are: quartz $-52.4 \%$; kaolinite - 34.13\%, sericite, hydromica -- $6.1 \%$, chlorite - few grains, goethite, limonite- $3.33 \%$, scorodite $-0.57 \%$, carbonaceous matter $-0.73 \%$, jarosite, gypsum - few grains, pyrite $0.2 \%$, arsenopyrite $-0.76 \%$.

The study of the granulometric composition of the original ore (Table 3) showed an increase in the gold content from large to fine grades. For the $+5 \mathrm{~mm}$ class the average content was $0.81 \%$, for the $5 \mathrm{~mm}$ class it was $1.29 \%$ with a distribution of $48.63 \%$ and $51.37 \%$, respectively. Preliminary screening of ore with the aim of separating metal-depleted classes is not rational.

Table 3. Granulometric characteristics of the ore sample of the "Adzhibugut" deposit, crushed to a size class of $2 \mathrm{~mm}$

\begin{tabular}{|c|c|c|c|c|c|c|c|c|}
\hline \multirow{2}{*}{$\begin{array}{c}\text { Size class, } \\
\mathbf{m m}\end{array}$} & \multirow{2}{*}{$\begin{array}{c}\text { Output, } \\
\mathbf{\%}\end{array}$} & \multicolumn{7}{|c|}{ Content of elements, \% } \\
\cline { 3 - 9 } & $\mathbf{A u}, \mathbf{g} / \mathbf{t}$ & $\mathbf{A g}, \mathbf{g} / \mathbf{t}$ & $\mathbf{S}_{\text {total }}$ & $\mathbf{S}_{\text {sulph }}$ & $\mathbf{F e}_{\text {total }}$ & $\mathbf{C O}_{2}$ & $\mathbf{C}_{\text {organ }}$ \\
\hline$-2+1$ & 37.2 & 1.40 & 1.60 & 0.91 & 0.69 & 3.30 & 0.18 & 1.03 \\
\hline$-1.0+0.5$ & 19.2 & 1.40 & 1.90 & 1.30 & 1.0 & 3.30 & 0.22 & 0.86 \\
\hline$-0.5+0.25$ & 13.5 & 1.30 & 1.90 & 1.60 & 1.21 & 3.50 & 0.22 & 0.88 \\
\hline$-0.25+0.16$ & 5.2 & 2.0 & 2.10 & 1.69 & 1.43 & 3.60 & 0.22 & 0.84 \\
\hline$-0.16+0.074$ & 7.5 & 2.10 & 2.80 & 2.24 & 1.90 & 3.80 & 0.26 & 0.78 \\
\hline$-0.074+0$ & 17.3 & 2.70 & 2.90 & 2.52 & 2.10 & 3.50 & 0.26 & 1.05 \\
\hline Total & 100.0 & 1.70 & 2.04 & 1.50 & 1.19 & 3.41 & 0.22 & 0.95 \\
\hline
\end{tabular}

The extraction of gold during the sorption cyanidation of the initial sample according to the scheme of resin in the "head" for 18 hours was $87 \%$, with a gold content in the tailings of $0.13 \mathrm{~g} / \mathrm{t}$.

Based on the studies carried out, the best indicators for the processing of oxidized ore from the Adzhibugut deposit were obtained according to the scheme of direct sorption cyanidation.

Beshashi. 
The content in the original ore of the Beshashi deposit was: gold $-1.75 \%$, silver $-0.2 \%$, sulfide sulfur -0.2 , arsenic $0.19 \%, \mathrm{Fe}-3.8 \%$.

Granulometric analysis showed (Table 4) that in crushed ore up to a size class of $2 \mathrm{~mm}$, the elements are redistributed into a finished class. When the output of the class is $0.074 \mathrm{~mm}$ $17.9 \%$, the gold content is $2 \mathrm{~g} / \mathrm{t}$, silver $0.3 \mathrm{~g} / \mathrm{t}$, with the distribution in this class of $20.825 \%$ gold and $23.26 \%$ silver.

Table 4. Granulometric characteristics of an ore sample from the Beshashi deposit, crushed to a size class of $2 \mathrm{~mm}$

\begin{tabular}{|c|c|c|c|c|c|c|c|c|}
\hline \multirow{2}{*}{$\begin{array}{c}\text { Size class, } \\
\mathbf{m m}\end{array}$} & \multirow{2}{*}{$\begin{array}{c}\text { Output, } \\
\mathbf{\%}\end{array}$} & \multicolumn{7}{|c|}{ Content of elements, \% } \\
\cline { 3 - 9 } & $\mathbf{A u , g / t}$ & $\mathbf{A g}, \mathbf{g} / \mathbf{t}$ & $\mathbf{S}_{\text {total }}$ & $\mathbf{S}_{\text {sulph }}$ & $\mathbf{F e}_{\text {total }}$ & $\mathbf{C O}_{2}$ & $\mathbf{C}_{\text {organ }}$ \\
\hline$-2+1$ & 35.1 & 1.90 & 0.20 & 0.47 & 0.20 & 4.10 & 0.10 & 0.10 \\
\hline$-1.0+0.5$ & 18.5 & 1.70 & 0.20 & 1.06 & 0.20 & 4.10 & 0.10 & 0.10 \\
\hline$-0.5+0.25$ & 10.8 & 1.70 & 0.20 & 0.98 & 0.20 & 4.0 & 0.10 & 0.10 \\
\hline$-0.25+0.16$ & 5.4 & 1.30 & 0.20 & 0.86 & 0.20 & 4.0 & 0.26 & 0.10 \\
\hline$-0.16+0.074$ & 12.5 & 1.0 & 0.30 & 0.89 & 0.20 & 3.3 & 1.58 & 0.10 \\
\hline$-0.074+0$ & 17.9 & 2.0 & 0.30 & 0.98 & 0.20 & 4.0 & 2.53 & 0.14 \\
\hline Total & 100.0 & 1.72 & 0.23 & 0.80 & 0.20 & 3.97 & 0.73 & 0.11 \\
\hline
\end{tabular}

Rational analysis showed the presence of $90.3 \%$ free cyanide gold in the sample.

The extraction of gold from the original ore by sorption cyanidation for 18 hours according to the scheme of resin in the "head" of the process was $89.7 \%$, the content in the sorption tailings was $0.18 \mathrm{~g} / \mathrm{t}$.

\section{Discussion}

Based on the studies carried out, we consider the most rational scheme for the direct sorption cyanidation of the initial pulp.

The qualitative and quantitative composition, the ratio of ore and rock minerals, the quantitative composition of easily slurry and solid minerals, the nature of their size and uniformity of distribution over the ore body determine the choice of averaging technology, crushing, crushing, screening, classification and enrichment methods.

The results obtained made it possible to determine the reasons for the decrease in ore preparation indices under conditions of significant variability of the physical and mechanical properties of the ore, and to establish a close relationship in the quantitative ratio of ores of different deposits, justifying the use of these parameters when choosing the best technological modes and optimization in the management of ore preparation processes. To analyze the granulometric composition of the ore in the $0.074 \mathrm{~mm}$ class, a comparative assessment method was applied. 


\section{Conclusion}

As a result of the studies, the problem of increasing the efficiency of ore preparation was solved based on the use of chemical analysis of the granulometric composition of the processed ore (charge), which provided an increase in the extraction of the useful component, which makes the model of the charge of ores from various deposits more accurate.

\section{References}

1. P.G. Spry, S. Chryssoulis, C.G. Ryan, JOM, 56:8, 60-62 (2004)

2. B.C. Huffman, J.D. Mensik, L.B. Riley, Determination of Gold in Geologic Materials by Solvent Extraction and Atomic-Absorption Spectrometry (Springer, Berlin, 1967)

3. S.L. Ramesh, P.V. Sunder Raju, K.V. Anjaiah, Ramavathi Mathur, T. Gnaneswara Rao, B. Dasaram, S. Nirmal Charan, D.V. Subba Rao, D.S. Sarma, M. Ram Mohan, V. Balaram, Atomic Spectroscopy 22:1, 263-269 (2001)

4. J. E. Hoffmann, Gold processing (Encyclopedia Britannica, London, 2008)

5. J.C. Yannopoulos, The Extractive Metallurgy of Gold (Springer, Berlin, 1991)

6. A. Sekisov, A. Rasskazova, Minerals, 11:69 (2021)

7. Xin-yuan Nan, Xin Cai , Jun Kong, ISIJ International, 54:3, 543-547 (2014)

8. T.N. Aleksandrova, G. Heide, A.V. Afanasova, Metallurgy and Mineral Processing, 235, 30-37(2019)

9. M.D. Adams, Advances in gold ore processing (Springer, Berlin, 2005)

10. A.E. Vorobyov, V.I. Lyashenko, T. Honore, K.A. Vorobyev, Metallurgical and Mining Industry, 7, 26-34 (2019) 